\title{
Eloria subapicalis (Lepidoptera: Noctuidae: Lymantriinae): rare and specialist species on Erythroxylum (Erythroxylaceae) in the cerrado
}

\author{
Ivone R. Diniz"1, 3; Cintia Lepesqueur'; Michelle S. Milhomen; \\ Fabiana C. S. Bandeira ${ }^{1} \&$ Helena C. Morais ${ }^{2}$
}

\author{
1 Departamento de Zoologia, Instituto de Ciências Biológicas, Universidade de Brasília. 70910-900 Brasília, DF, Brazil. \\ ${ }^{2}$ Departamento de Ecologia, Instituto de Ciências Biológicas, Universidade de Brasília. 70910-900 Brasília, DF, Brazil. \\ E-mail: morais@unb.br \\ ${ }^{3}$ Corresponding author. E-mail: irdiniz@unb.br
}

\begin{abstract}
Eloria subapicalis (Walker, 1855) is a rare species (61 individuals in four years of samplings) of Noctuidae (Lymantriinae) with a specific diet consisting of leaves of Erythroxylum P. Browne (Erytroxylaceae) species in Brasilia's cerrado. Generally, the rarity of a caterpillar species may have many explanations such as a generalist diet, being restricted to a host plant that is scarce in the area, or occurring in a limited geographical area. However, all the above explanations do not apply to E. subapicalis because it shows specificity of diet, uses a common host plant in the cerrado areas, and has a large geographical distribution.
\end{abstract}

KEY WORDS. Abundance; diet specificity; folivorous caterpillar; host plants; moths.

Herbivorous insects may be generalists or specialists. Specialists feed on a few phylogenetically related species which generally have similar chemical compounds (BERNAYs \& CHAPMAN 1994). The diets of lepidopterans living in the tropics are often more specialized than the diets of temperate species (DYER et al. 2007). When a caterpillar species in the cerrado feeds specifically on a genus or family of plants, it is generally also abundant on its hosts (e.g. Pessoa-Queiroz et al. 2008). However, a few specialized caterpillar species in the cerrado seem to be rare (e.g. MoraIs \& Diniz 2003).

Two decades of studies in the cerrado have revealed a low frequency of folivorous caterpillars and a prevalence of rare species on their host plants (Price et al. 1995, Morais et al. 1996, Bendicho-López et al. 2003, Morais \& Diniz 2003, 2004). Because cerrado caterpillars are found in low frequencies and low densities on plants, data collection is very time consuming, resulting in rare or scarce species being overlooked by researchers.

The lymantriines were previously considered to be a separate family (Lymantriidae) but are presently recognized as a subfamily within Noctuidae (KRISTENSEN et al. 2007). They are found all over the world, except in Antarctica, and are particularly abundant in tropical Africa, India, Southeast Asia, and South America (EOL 2010). Lymantriines are represented in the cerrado plants of Brasília by only four species: Eloria subapicalis (Walker, 1855), a relatively abundant species Thagona tibialis (Walker, 1955); and two unidentified species of Caviria (Diniz et al. 2001). Adult Lymantriinae have a short lifespan, a reduced haustellum, and do not feed (Costa Lima 1949). Cater- pillars are hairy, usually colorful, and remain in the cocoon (where they incorporate larval hairs) when pupating. Many lymantriines are known for being plant pests and some bear urticating hairs that can lead to mild skin irritation to serious dermatitis in man (SCOBLE 1992).

Eloria Hübner, 1819 recently contains 80 species (BECCALONi et al. 2010). However, host plant information is available for only four species: two in Brazil (SiLva et al. 1968), one in Peru (Chen et al. 2006), and one in Costa Rica (JANZen \& Hallwachs 2010). In cerrado, E. subapicalis is specialized on species of the plant genus Erythroxylum P. Browne (Erythroxylaceae) (Diniz et al. 2001).

Ordinarily, studies on Lepidoptera concern the most common species, and data on rare species in any ecosystem are difficult to find. Because rare species in the tropics represent a high proportion of the species in insect communities, they are very important in biodiversity assessments. Furthermore, they may be crucial to understanding the maintenance of small populations in the ecosystem over the long-term (Novotny \& Basset 2000, Novotny et al. 2002, Kean \& Barlow 2004). Eloria subapicalis is noteworthy because its host plants are fairly common in the cerrado (FelfiLI \& SILVA JR 1993) but their caterpillars are rare. In this paper, we present data on E. subapicalis caterpillars that feed on common species of Erythroxylum in a cerrado at Brazil Central. This information was collected for three consecutive years (1995 to 1997), and a decade later, during one year (September 2005 to August 2006), and aims to provide a backdrop for discussing cerrado lepidopteran rarity and restricted diets. 


\section{MATERIAL AND METHODS}

This study was carried out in areas of cerrado sensu stricto (Oliveira-Filho \& Ratter 2002) at the Experimental Station of the University of Brasília (FAL), $15^{\circ} 55^{\prime} \mathrm{S}, 47^{\circ} 55^{\prime} \mathrm{W}$, Distrito Federal, Brazil. The region has an average annual temperature of $22^{\circ} \mathrm{C}$ and average annual precipitation of $1,431 \mathrm{~mm}$, with a well-defined dry season lasting from May to September (IBGE 2009). Further information on the soil and vegetation in the area is available in Ratter (1991), Felfil et al. (1994), and Eiten (2001).

The four plant species monitored for caterpillars were: Erythroxylum deciduum St.-Hil., E. tortuosum Mart., E. suberosum St.-Hil., and E. campestre St.-Hil. Erythroxylum is represented by 10 species in the cerrado of the Distrito Federal (Cavalcanti \& RAmos 2001) - four in gallery forests and six in the cerrado sensu stricto.

Surveys were carried out at the same 4 ha of cerrado sensu stricto in all three sampling periods, and using the same methodology. We monitored caterpillars weekly, covering the entire foliage of 15 to 25 individuals of each Erythroxylum species during three periods: 1) from February 1995 to September 1997, on 5,150 plants belonging to E. deciduum, E. suberosum, and $E$. tortuosum; 2) from September 1996 to August 1997 on 690 plants belonging to E. campestre; and 3) from September 2005 to August 2006 on 4,196 plants belonging to E. deciduum and $E$. tortuosum. Since the study site was partially and accidentally burned in August 2005, the third sampling event occurred on both burned and unburned areas with approximately 2 ha each; 2,065 individuals of $E$. deciduum and E. tortuosum were sampled in an unburned portion of the study site and 2,131 in a burned portion.

The caterpillars of E. subapicalis (Fig. 1), have long yellowish hairs, dark green tegument with a central yellow stripe and a reddish head; they attain a length of $4 \mathrm{~cm}$ in their final stage, and the pupal cocoon is built with leaves and silk (Fig. 2). All $E$. subapicalis caterpillars found were collected and reared in plastic jars in the laboratory without temperature, light or humidity control, and fed on leaves of the plant on which they were found. Observation on larval behavior was performed in the field and in the laboratory. Dates of pupation, emergence of the adult moth and/or of parasitoids were recorded. Dr Vitor O. Becker identified the genus or species, and adult (Fig. 3) voucher specimens were added to the 'Coleção Entomológica do Departamento de Zoologia da Universidade de Brasília (CEDZ/UnB)'.

\section{RESULTS}

The caterpillars cut marginal portions of the leaves and avoid the central vein. They were located exposed and isolated in the abaxial portion of mature and new leaves, and on trunks. The pupation occurs within a cocoon covered with a layer of silk and leaves (Fig. 2). The average pupation time in laboratory $(\mathrm{n}=8)$ was 13 days $(\mathrm{sd}=10)$ and parasitism was not recorded for either larvae or pupae.
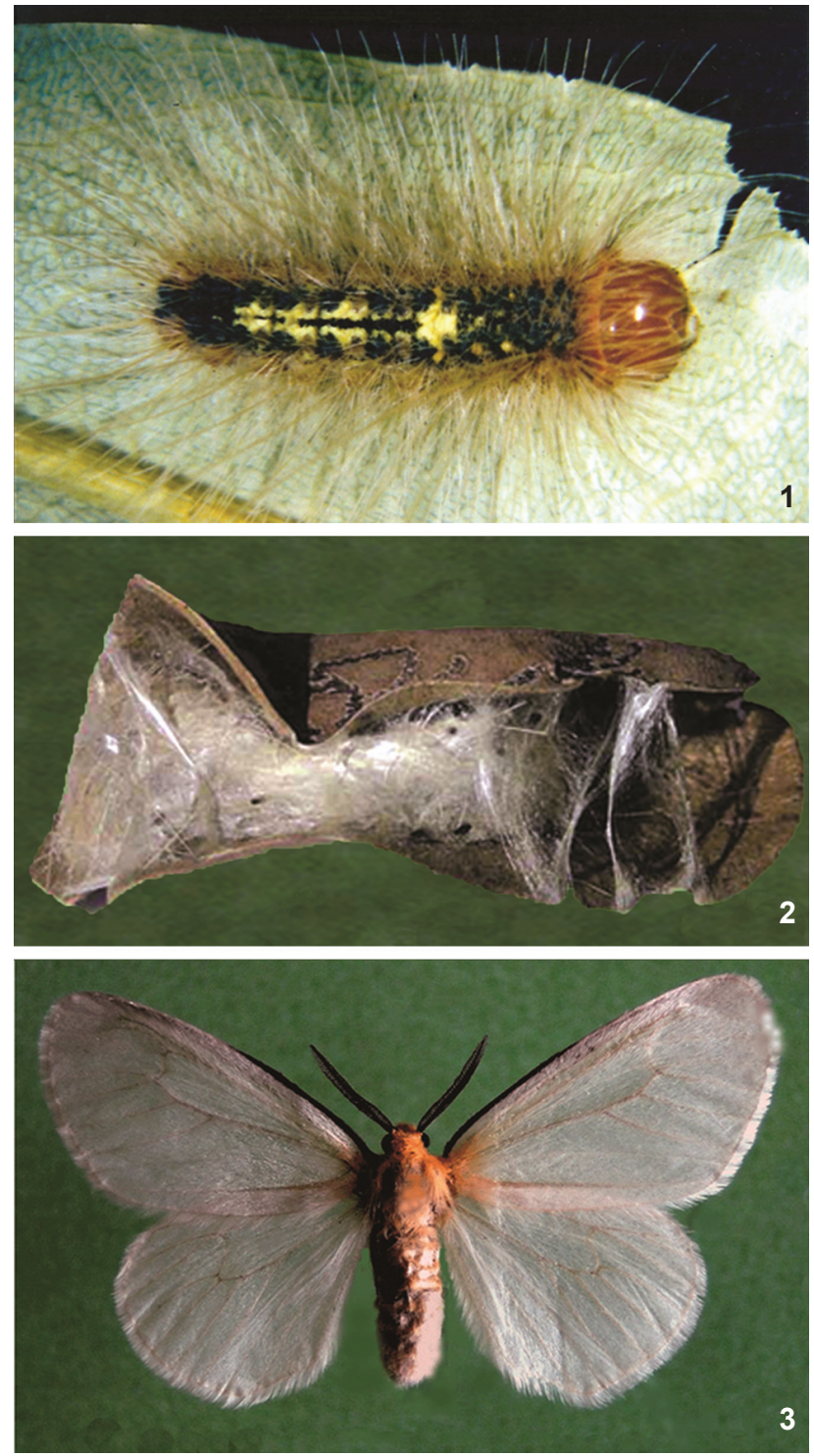

Figures 1-3. Eloria subapicalis: (1) caterpillar on Erythroxylum suberosum in the cerrado area at Fazenda Água Limpa, Experimental Station, Distrito Federal, Brazil; (2) pupa cocoon; (3) adult.

A total of 54 E. subapicalis caterpillars were found on 5,150 plants examined during the first period of sampling, of which $50 \%$ were located on E. tortuosum, $46 \%$ on E. suberosum and $4 \%$ on E. deciduum. No caterpillar was found on E. campestre during the second period of sampling. In the third period of sampling (4,196 plants examined) only seven caterpillars were found between January and March 2006, all on mature leaves of $E$. tortuosum and only in the burned portion of the study site.

The abundance of E. subapicalis varied throughout the year, and between years. The caterpillars use E. tortuosum and 
E. suberosum in a similar way (Fig. 4). Two generations of caterpillars appear to occur during a year, one during the dry season, beginning from April to July and extending until September, and another during the rainy season, from November to February.

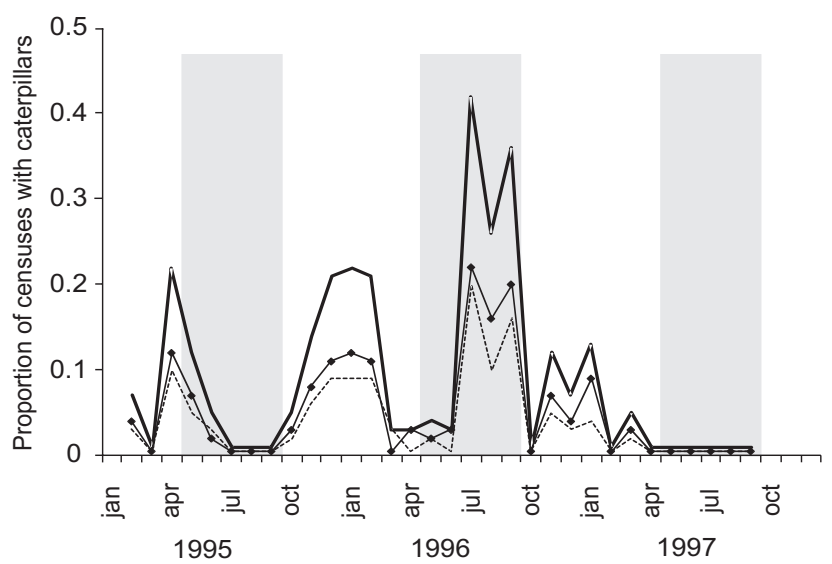

Figure 4. Monthly occurrence of Eloria subapicalis caterpillars on two species of Erythroxylum in the cerrado at Fazenda Água Limpa, Distrito Federal, Brazil. The gray bar indicates the dry season (MaySeptember) in the region, black full line = proportion of caterpillars on the two species of hostplants, dotted line = proportion of caterpillars on E. suberosum, and gray full line = proportion of caterpillars on E. tortuosum.

\section{DISCUSSION}

Lymantriinae was seldom represented in the folivorous caterpillar surveys conducted in cerrado areas of the Distrito Federal (Diniz et al. 2001). There is scant information in the literature about the host plants associated with Eloria (as summarized in Tab. I). All five species of Eloria for which we obtained information from the literature also used Erythroxylum and three of them also used other plants as hosts (SiLVA et al. 1968, CHEN et al. 2006, JANZEN \& HaLlWACHS 2010). However, specimens of Eloria were rarely found, or not found at all, on some species Erythroxylum. This is the case of E. campestre (no Eloria caterpillars found) and E. deciduum (only two caterpillars) in the present study. In another study, conducted at the restinga area in Rio de Janeiro (MonTEIRo et al. 2007), Eloria caterpillars were not found on E. ovalifolium Peyr. and E. subsessile (Mart.) O. E. Schulz Caterpillars belonging to Eloria noyesi Schaus, 1927 present detoxification and dopamine sequester mechanisms that allow them to use E. coca Lam. as a host plant (CHEN et al. 2006). The leaves of $E$. campestre and $E$. deciduum have cocaine, whereas the leaves of E. suberosum do not (BIERI et al. 2006); thus, it is possible that E. subapicalis selects its host plants according to the chemical constitution of their leaves.

Eloria subapicalis caterpillars seem to be local specialists on Erythroxylum occurring predominantly on E. tortuosum and E. suberosum. This hypothesis is based on our database obtained since 1991 for caterpillars in the cerrado vegetation of the Distrito Federal, on more than 30,000 plants of 100 species, and on more than 5,000 adults reared in the laboratory (DINIZ et al. 2001 and unpublished data). This database, far from complete due to the great plant diversity of the cerrado, is the largest for caterpillars and their host plants in the biome. It encompasses $76 \%$ of plant Index value of importance (IVI) (Fonseca \& Silva JR 2004), and to $80 \%$ of basal area (Felfili et al. 2000). Erythroxylum tortuosum and E. suberosum represent the major biomass and densities of this genus in the cerrado sensu stricto (Felfili \& Silva JR 1993). Despite the abundance of host plants in the area, caterpillars are rare. Usually, in the cerrado, caterpillars specialize on abundant host plants and use a small portion of the available resources ( $10 \%$ to $25 \%$ of the plants), but are abundant on these (Bendicho-López et al. 2003, Morais et al. 2005). However, this is not the case of E. subapicalis, which is a rare species on Erytroxylum in the cerrado of the Distrito Federal.

Table I. Available information on host plants of Eloria species.

\begin{tabular}{|c|c|c|c|c|}
\hline \multirow{2}{*}{ Eloria species } & \multicolumn{2}{|r|}{ Host Plants } & \multirow{2}{*}{ Location } & \multirow{2}{*}{ Reference } \\
\hline & Erythroxylum & Others & & \\
\hline E. moeonia & E. pelleterianum & Apuleia (Fabaceae) & RS & SILVA et al. 1968 \\
\hline E. noyesi & E. coca & $?$ & Peru & CHEN et al. 2006 \\
\hline E. spectra & E. pelleterianum & Apuleia (Fabaceae) Malvaceae & $E S, R J, R S$ & SILVA et al. 1968 \\
\hline \multirow[t]{3}{*}{ E. subapicalis } & E. deciduum & & & \\
\hline & E. suberosum & - & DF & This study \\
\hline & E. tortuosum & & & \\
\hline E. torrida & E. macrophyllum & Polyphagous, mainly on species of Eugenia & Costa Rica & Janzen \& Hallwachs 2010 \\
\hline
\end{tabular}

States in Brazil: (DF) Distrito Federal, (ES) Espírito Santo, (RJ) Rio de Janeiro, (RS) Rio Grande do Sul. 
There are several possible explanations for the rarity of these caterpillars in the cerrado. One could be population control by natural enemies. Even though egg parasitism and predators were not examined in this study, they are important factors affecting moth populations (KIDD \& JeRvis 1997). Laboratoryreared E. subapicalis, however, were not parasitized. Another explanation would be the effect of the dry season, which lasts five months in the cerrado region. However, in the studied cerrado areas E. subapicalis caterpillars occur on Erythroxylum during both dry and wet seasons. Therefore, the long cerrado dry season does not constitute a limiting factor for these caterpillars.

Four other species of Erythroxylum are common in gallery forests of the Distrito Federal (Cavalcanti \& Ramos 2001). Another possible explanation for the rarity of E. subapicalis caterpillars in their cerrado host plants would be the use of other Erythroxylum species in gallery forests. This hypothesis was proposed to explain the low densities of caterpillars of Siderone galanthis galanthis (Cramer) (Nymphalidae) in its cerrado host plant (Morais et al. 1996).

The distribution of some species may be considered sparse, with many small populations dispersed throughout a broad geographical region (KEAN \& BARLOW 2004). Thus, a fourth possible explanation is that this species is locally rare (61 caterpillars in four years of research), but has a large geographical distribution. Eloria subapicalis is known to occur in Venezuela (local type) and also in the French Guiana (Collenette 1950), but there is no additional published information on its phenology.

At least three species of Eloria are polyphagous (SILVA et al. 1968, JANZEN \& HaLLWACHS 2010) but E. subapicalis is restricted to Erythroxylum in this region. Another rare and specialized moth species found in the Cerrado, Aucula munroei Todd \& Poole, 1981 (Noctuiidae: Agarastinae), was found only on Davilla elliptica (Dilleniaceae) (see Morais \& Diniz 2003) in our limited Cerrado study area, but other agaristine species are found on several host species in a broad geographical distribution, feeding on Vitaceae and other 13 unrelated families, including Dilleniaceae (Rawlins 1992). Most of these plant families are available in the cerrado.

The moth fauna of the Cerrado is clearly dominated by rare species with basically unknown natural histories (PRICE et al. 1995, Morais \& Diniz 2003, Diniz \& Morais 2005). Information on the biology, diet amplitude, and use of habitats by these species would provide a basic information network for decision making on the conservation of the cerrado biome. This study suggests that, in the cerrado, E. subapicalis caterpillars specialize on Erythroxylum species, occur seasonally, and do not occur in densities that reflect those of their host plant. This trend corroborates the prevalent pattern of the cerrado caterpillars, where they occur in low densities relative to resource availability (PRICE et al. 1995). Also, top-down pressure does not seem to be very important in regulating this caterpillar population because none of the caterpillars collected were attacked by parasitoids. However, we know little about egg parasitism and predation.
Further studies are needed to understand the underlying factors shaping our results, and to clarify the questions they raise. It is also necessary to investigate the presence of E. subapicalis on Erythroxylum species in gallery forests of other cerrado areas, and whether individuals of this species make better use of host plants in areas that have been burned previously, like other species in this cerrado area (Diniz \& Morais 2008).

\section{ACKNOWLEDGEMENTS}

We thank Regina H. Ferraz Macedo (University of Brasilia), two anonymous referees, and the editor for helpful comments and criticism on the manuscript;Vitor O. Becker for the identification of the Lepidoptera; administrators of Experimental Station (Fazenda Água Limpa - FAL) of the University of Brasilia for facilitating our field work. CL received a CAPES (Federal Agency for High Education Capacity Building) scholarship, MSM and FCSB received a grant of research initiation from $\mathrm{CNPq} / \mathrm{UnB}$ (National Council for Scientific and Technological Development/University of Brasilia) scholarships, and the project was supported by CNPq and FAPDF (Federal District Foundation for Science and Research Supporting).

\section{LITERATURE CITED}

Becalloni, C.W.; M.J. Scoble \& G.S. Robinson. 2010. The global Lepidoptera names Index (LepIndex). Available online at: http://www.nhm.ac.uk/entomology/lepindex [Accessed: 2.II.2010].

Bendicho-López, A.; I.R. Diniz \& J.D. Hay. 2003. Abundance of Chlamydastis platyspora (Elachistidae) on its host plant Roupala montana Aubl. (Proteaceae) in relation to leaf phenology. Journal of the Lepidopterist' Society 57: 127-134.

Bernays, E.A. \& R.F. Chapmam. 1994. Host-plant selection by phytophagous insects. New York, Chapman \& Hall, 312p.

Bieri, S.; A. Brachet; J.L. Veuthey \& P. Christen. 2006. Cocaine distribution in wild Erythroxylum species. Journal of Ethnopharmacology 103: 439-447.

Cavalcanti, T.B. \& A.E. Ramos. 2001. Flora do Distrito Federal, Brasil. Brasília, EMBRAPA Cenargen, 359p.

Chen, R.; X. Wu; W. Wei; D.D. Han \& H.H. Gu. 2006. Molecular cloning and functional characterization of the dopamine transporter from Eloria noyesi, a caterpillar pest of cocainerich coca plants. Gene 366: 152-160.

Collenette, C.L. 1950. A revision of the genus Eloria Walker (Heterocera, Lymantriidae). Annals and Magazine of Natural History 12: 813-865.

Costa Lima, A.M. 1949. Insetos do Brasil. Rio de Janeiro, Escola Nacional de Agronomia, Tomo 6.

Diniz, I.R. \& H.C. Morais. 2005. Abundância e amplitude de dieta de lagartas no cerrado de Brasília, DF, p. 306-318. In: A. Scariot; J.C. Sousa-Silva \& J.M. Felfili (Eds). Cerrado: ecologia, biodiversidade e conservação. Brasília, Ministério do Meio Ambiente, 439p. 
DinIz, I.R. \& H.C MoraIs. 2008. Efeito do fogo na abundância de insetos no Cerrado: o que sabemos? Heringeriana 2: 39-46.

Diniz, I.R.; H.C. Morais \& A.J.A. Camargo. 2001. Host plants of lepidopteran caterpillars in the cerrado of the Distrito Federal, Brazil. Revista Brasileira de Entomologia 45: 107-122.

Dyer, L.A.; M.S Singer; J.T. Lill; J.O. StiReman; G.L. Gentry; R.J. Marquis; R.E. Ricklefs; H.F. Greeney; D.L. Wagner; H.C. MoRAIS; I.R. Diniz; T.A. KuRSAR \& P.D. COLEy. 2007. Host specificity of Lepidoptera in tropical and temperate forests. Nature 448: 696-699.

Eiten, J. 2001. Vegetação natural do Distrito Federal. Brasília, Editora UnB, Edição SEBRAE, 162p.

EOL. 2010. Encyclopedia of Life. Available online at: http:// www.eol.org [Accessed: 15.VI.2010].

Felfili, J.M. \& M.C. Silva JR. 1993. A comparative study of cerrado (sensu stricto) vegetation in central Brazil. Journal of Tropical Ecology 9: 277-289.

Felfili, J.M.; M. Haridasan; R.C. Mendonça; T.S. Filgueiras; M.C. Silva JR \& A.V. Rezende. 1994. Projeto Biogeografia do Bioma Cerrado: vegetação e solos. Caderno de Geociências 12: 75-166.

Felfili, J. M.; A.V. Rezende; M.C. Silva Jr \& A. Silva. 2000. Changes in the floristic composition of cerrado sensu stricto in Brazil over a nine-year period. Journal of Tropical Ecology 16: 579-590.

FonseCa, M.S. \& M.C. Silva JR. 2004. Fitossociologia e similaridade florística entre trechos de Cerrado sentido restrito em interflúvio e em vale no Jardim Botânico de Brasília, DF. Acta Botanica Brasilica 18: 19-29.

IBGE. 2009. Reserva Ecológica do Instituto Brasileiro de Geografia e Estatística. Available on line at: http:// www.recor.org.br [Accessed: 13.VI.2009].

Janzen, D.H. \& W. Hallwachs. 2010. Dynamic database for an inventory of the macrocaterpillar fauna, and its food plants and parasitoids, of Area de Conservación Guanacaste (ACG), Costa Rica. Available on line at: http:/ /janzen.sas.upenn.edu [Accessed: 14.V.2010].

KEAN, J. \& N. BARLOW. 2004. Exploring rarity using a general model for distribution and abundance. American Naturalist 163: 407-416.

KIDD, N.A.C. \& M.A. Jervis. 1997. The impact of parasitoids and predators on forest insect populations, p. 49-68. In: A.D. WATT; N.E. STORK \& M.D. Hunter (Eds). Forest and Insects. London, Chapman \& Hall.

Kristensen, N.P.; M.J. Scoble \& O. Karsholt. 2007. Lepidoptera phylogeny and systematics: the state of inventorying moth and butterfly diversity. Zootaxa 1668: 699-747.

Monteiro, R.F.; M.V. MACEDO; M.S. NASCIMENTO \& R.S.F. CuRY. 2007. Composição, abundância e notas sobre a ecologia de espécies de larvas de lepidópteros associadas a cinco espécies de plantas hospedeiras no Parque Nacional da Restinga de Jurubatiba, RJ. Revista Brasileira de Entomologia 51: 476483.
Morais, H.C. \& I.R. Diniz. 2003. Larva and host plant of the Brazilian cerrado moth Aucula munroei (Lepidoptera: Noctuidae). Tropical Lepidoptera 11: 49-50.

Morais, H.C. \& I.R. Diniz. 2004. Herbívoros e herbivoria em cerrado: lagartas como exemplo, p. 159-175. In: L.M.S. AguiAR \& A.J.A. Camargo (Eds). Cerrado: ecologia e caracterização. Planaltina, DF, Embrapa-CPAC.

Morais, H.C.; I.R. Diniz \& J.R. Silva. 1996. Larvas de Siderone marthesia nemesis (Illiger) (Lepidoptera: Nymphalidae, Charaxinae) em um cerrado de Brasília, Distrito Federal, Brasil. Revista Brasileira de Zoologia 13 (2): 351-356. doi:10.1590/S0101-81751996000200007.

MoraIs, H.C.; I.M. Mahajan \& I.R. DinIz. 2005. História natural da mariposa Chlamydastis smodicopa (Meyrick) (Lepidoptera, Elachistidae, Stenomatinae). Revista Brasileira de Zoologia 22 (3): 633-638. doi:10.1590/S0101-81752005000300016.

Novotny, V.Y. \& Y. BASSET. 2000. Rare species in communities of tropical insect herbivores: pondering the mystery of singletons. Oikos 89: 564-572.

Novotny, V.; Y. Basset; S.E. Miller; P. Drozd \& L. Cizek. 2002. Host specialization of leaf chewing insects in a New Guinea rainforest. Journal of Animal Ecology 71: 400-412.

Oliveira-Filho, A.T. \& J.A. RatTer. 2002. Vegetation physiognomies and woody flora of the Cerrado Biome, p. 91-120. In: P.S. Oliveira \& R.J. Marquis (Eds). The cerrados of Brazil. New York, Columbia University Press.

Pessoa-Queiroz, R.; I.R. Diniz \& H.C. Morais. 2008. Abundance and temporal distribution of Gonioterma exquisita Duckworth (Lepidoptera, Elachistidae, Stenomatinae) on Byrsonima pachyphylla Griseb. (Malpighiaceae) in the Brazilian Cerrado. Revista Brasileira de Entomologia 52: 62-67.

Price, P.W.; I.R. Diniz; H.C. Morais \& E.S.A. Marques. 1995. The abundance of insect herbivore species in the tropics: the high local richness of rare species. Biotropica 27 (4): 468-478.

Ratter, J.A. 1991. Notas sobre a vegetação da Fazenda Água Limpa (Brasília, DF). Brasília, Editora UnB, Textos universitários 3, 136p.

Rawlins, J.E. 1992. Life history and systematics of the West Andean moth Aucula franclemonti with description of a new species from Ecuador (Lepidoptera: Noctuidae: Agarastinae). Journal of New York Entomological Society 100: 286-310. Scoвle, M.J. 1992. The Lepidoptera. Oxford University, XI+404p. Silva, A.G.D'A.; C.R. Gonçalves; D.M. Galvão; A.J.L. Gonçalves; J. Gomes; M. Do N. Silva \& L. DE Simoni. 1968. Quarto catálogo dos insetos que vivem nas plantas do Brasil, seus parasitos e predadores. Edição ampliada do " $3^{\circ}$ catálogo dos insetos que vivem nas plantas do Brasil" de autoria do Prof. A. M. da Costa Lima. Parte II. Insetos, hospedeiros e inimigos naturais. Índice de insetos e índice de plantas. Rio de Janeiro, Ministério da Agricultura, vol. 1, XXVII+622p.

Submitted: 13.I.2010; Accepted: 21.IX.2010.

Editorial responsibility: Pedro Gnaspini 